\title{
Analysis of Online Learning Readiness in College Students and Its Implications for Higher Education
}

\author{
Elmanora $^{1}$, Maya Oktaviani ${ }^{2}$, Shinta Doriza $^{3}$ \\ \{shintadoriza@unj.ac.id\} \\ Family Welfare Education, Faculty of Engineering, Universitas Negeri Jakarta ${ }^{123}$
}

\begin{abstract}
Readiness to learn online is a determining factor for student success in learning, especially in the digital era. This study aims to analyze online learning readiness among students at a state university in Jakarta, Indonesia. This study involved 245 college students who were randomly selected. Measurement of online learning readiness data uses the Student Online Learning Readiness or SOLR (Yu \& Richardson, 2015). SOLR instruments consist of four dimensions: technical competence, social competence with the instructor, social competence with classmates, and communication competence. This instrument consists of 20 statement items. The data that has been collected is processed and analyzed using descriptive statistics. The results showed that students' online learning readiness was quite a good category. The implications of this study will be discussed.
\end{abstract}

Keywords: Online Learning; SOLR; Higher Education

\section{Introduction}

Higher education is the spearhead of nation-building. Higher education must be able to produce graduates who have competencies that are by what is needed by the world of work. Higher education institutions need to adapt to changes that occur in the surrounding environment, such as changes in technology. Higher education must be able to take advantage of technological advances to produce quality human resources. To produce quality graduates, universities make various changes in the implementation of learning. One of them is the change in learning methods from classical to blended learning and fully online. The first step that universities must take is to prepare students to take part in online learning activities (Forson \& Vuopala, 2019). Student readiness in learning will determine the success of online learning (Blayone, 2018). Students need to have good abilities to reflect on their attributes as online learners, time management, communication, and technical skills (Martin et al., 2020). Higher education is tasked with implementing e-learning and is also charged with preparing students for this learning (Adams et al., 2018).

Students who are ready to take part in online learning will have good self-directed learning. Self-directed learning is the primary determinant of student success (Cigdem \& Ozturk, 2016). The readiness of students to learn online can also increase positive perceptions of education and can also increase student satisfaction (Wei \& Chou, 2020). Based on this explanation, higher education needs to pay attention to the readiness of students participating in online learning. The reason is that this readiness is a predictor of success in achieving learning goals. For this reason, an analysis of student readiness in participating in online 
learning activities needs to be done. The results of the study can be considered by higher education in formulating efforts to improve the implementation of online learning in higher education (Coopasami et al., 2017). Therefore, this study aims to analyze student learning readiness in participating in online learning in tertiary institutions.

\section{Methodology}

This research is a descriptive study which aims to analyze the readiness of students in doing online learning. This study involved 245 students of Family Welfare Science, Faculty of Engineering, Universitas Negeri Jakarta who were selected by using a proportionate stratified random sampling technique. Online learning readiness data is measured using the Student Online Learning Readiness instrument or SOLR (Yu \& Richardson, 2015). The SOLR instrument consists of four dimensions, namely technical competence, social competence with instructors, social competence with classmates, and communication competence. This instrument consists of 20 statement items with a choice of responses, including disagree, tend to disagree, be neutral, tend to agree, and agree. The results of the validity and reliability test showed that the instrument used was valid and had a good reliability value, namely Cronbach's Alpha of 0.895. Data analysis used descriptive statistics to calculate the mean, frequency, and percentage values. Before doing data analysis, the data that has been counted and converted into an index (interval 1-100). Furthermore, the data is divided into three categories, namely low (index <60), medium (index 60 - 80), and high (index > 80) (Yimer et al., 2014).

\section{Result and Discussion}

\subsection{Technical Competence}

The first dimension of online learning readiness is technical competence ( $\mathrm{Yu} \&$ Richardson, 2015). Technical competence is measured by six points, namely self-confidence in using computer technology in doing specific tasks, proficiency in using computer-based technology, comfort in using computers, ability to explain the benefits of using computer technology in learning, being competent and able to integrate computer technology into the independent learning process, and being motivated. To engage in learning activities with computer technology. The distribution of students based on the responses to each item of the statement in technical competence is presented in Table 1, and the level of technical ability of students in online learning readiness is presented in Figure 1.

Table 1. Technical Competence of Students in Online Learning Readiness

\begin{tabular}{|c|c|c|c|c|c|c|}
\hline \multirow{2}{*}{ Item } & \multicolumn{5}{|c|}{ Percent } & \multirow{2}{*}{ Total } \\
\hline & 1 & 2 & 3 & 4 & 5 & \\
\hline $\begin{array}{l}\text { 1. Confidence in using computer technology in } \\
\text { doing specific tasks }\end{array}$ & 0 & 2.9 & 24.5 & 32.2 & 40.4 & 100.0 \\
\hline $\begin{array}{l}\text { 2. Proficiency in using computer-based } \\
\text { technology }\end{array}$ & 0.8 & 6.5 & 41.2 & 35.5 & 15.9 & 100.0 \\
\hline 3. Convenience of using a computer & 2.0 & 10.6 & 32.2 & 29.8 & 25.3 & 100.0 \\
\hline $\begin{array}{l}\text { 4. The ability to explain the benefits of using } \\
\text { computer technology in learning }\end{array}$ & 2.0 & 8.2 & 33.5 & 37.6 & 18.8 & 100.0 \\
\hline
\end{tabular}




\begin{tabular}{lcccccc}
\hline \multicolumn{1}{c}{ Item } & \multicolumn{7}{c}{ Percent } & \multirow{2}{*}{ Total } \\
\cline { 2 - 6 } & $\mathbf{1}$ & $\mathbf{2}$ & $\mathbf{3}$ & $\mathbf{4}$ & $\mathbf{5}$ & 100.0 \\
\hline $\begin{array}{l}\text { 5. Competent and able to integrate computer } \\
\text { technology into the personal learning process }\end{array}$ & 1.6 & 9.8 & 41.2 & 29.4 & 18.0 & 100.0 \\
$\begin{array}{l}\text { 6. Motivated to be involved in learning activities } \\
\text { with computer technology }\end{array}$ & 2.0 & 12.7 & 35.9 & 31.8 & 17.6 & 100.0 \\
\hline
\end{tabular}

Note: $1=$ Disagree, $2=$ Tend to disagree, $3=$ Neutral, $4=$ Tend to agree, $5=$ Agree

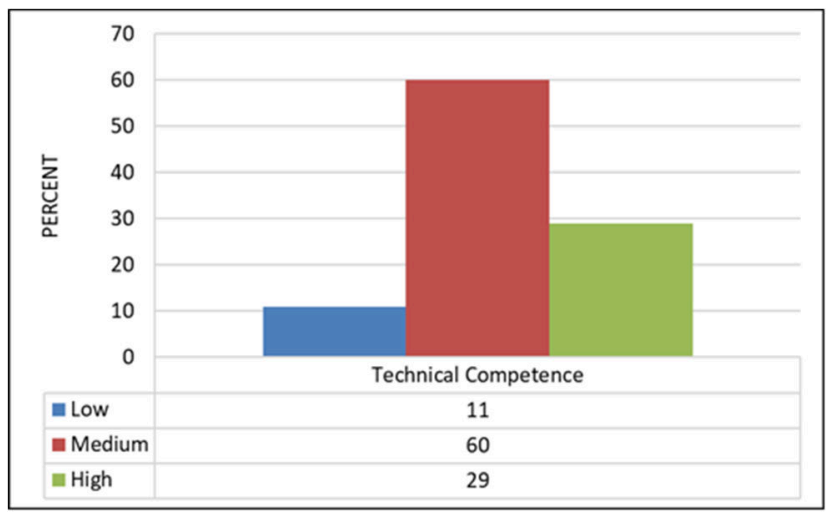

Fig 1. Level of technical competence

The results showed that six out of ten students had technical competence in the medium category, with an average score of 73.35. Students should have useful technical competence. The reason is that technical competence plays an essential role in building student readiness to learn online and also determines student success in learning online (Martin et al., 2020). These results indicate that the technical competencies possessed by students still need to be improved. The results presented in Table 1 show that there are still students who lack confidence in using computers, even though self-confidence in using computers is a significant predictor of technical competence (Garland \& Noyes, 2005). One way that higher education can do to increase student confidence in using computers is to encourage students to have computers. The availability of computers can encourage students to learn to use them (Cakir, 2012).

Repeated use will help students learn to use computers. Higher education institutions can also implement technical competency improvement programs for students, such as training to improve students' ability to use computers. In addition to improving technical competence, this activity can also increase student engagement (Schindler et al., 2017). Not all students have the ability to use technology well. Therefore, universities must also pay attention to the use of technology in implementing learning activities. Higher education institutions can convey clear instructions for using this technology to students (Ali, 2016).

\subsection{Social Competence with Lecturers}

The second dimension of online learning readiness is social competence with instructors (Yu \& Richardson, 2015). In this study, the instructor in question is a lecturer. Social competence with lecturers is measured by five statement items, namely self-confidence in being able to ask questions, starting discussions, ask for help when needed, tell timely when 
unexpected situations arise, and also respectfully convey opinions to lecturers. The distribution of students based on the responses to each statement item on social competence with lecturers is presented in Table 2, and the level of social competence between students and lecturers is presented in Figure 2.

Table 2. Social Competence of Students and Lecturers in Online Learning Readiness

\begin{tabular}{lcccccc}
\hline \multicolumn{1}{c}{ Item } & \multicolumn{7}{c}{ Percent } & Total \\
\cline { 2 - 6 } & $\mathbf{1}$ & $\mathbf{2}$ & $\mathbf{3}$ & $\mathbf{4}$ & $\mathbf{5}$ & \\
\hline $\begin{array}{l}\text { 1. Confidence in being able to ask questions } \\
\text { to the lecturer }\end{array}$ & 2.0 & 7.8 & 36.3 & 28.2 & 25.7 & 100.0 \\
$\begin{array}{l}\text { 2. Confidence in starting discussions with } \\
\text { lecturers }\end{array}$ & 0.8 & 11.0 & 48.2 & 24.1 & 15.9 & 100.0 \\
$\begin{array}{l}\text { 3. Confidence to ask for help from lecturers } \\
\text { when needed }\end{array}$ & 3.7 & 10.2 & 37.1 & 30.6 & 18.4 & 100.0 \\
$\begin{array}{l}\text { 4. Confidence to notify promptly when } \\
\text { unexpected situations arise }\end{array}$ & 1.2 & 6.5 & 37.6 & 32.2 & 22.4 & 100.0 \\
$\begin{array}{l}\text { 5. Confidence to convey opinions to lecturers } \\
\text { respectfully }\end{array}$ & 0.4 & 3.3 & 27.8 & 34.3 & 34.3 & 100.0 \\
\hline
\end{tabular}

Note: $1=$ Disagree, $2=$ Tend to disagree, $3=$ Neutral, $4=$ Tend to agree, $5=$ Agree

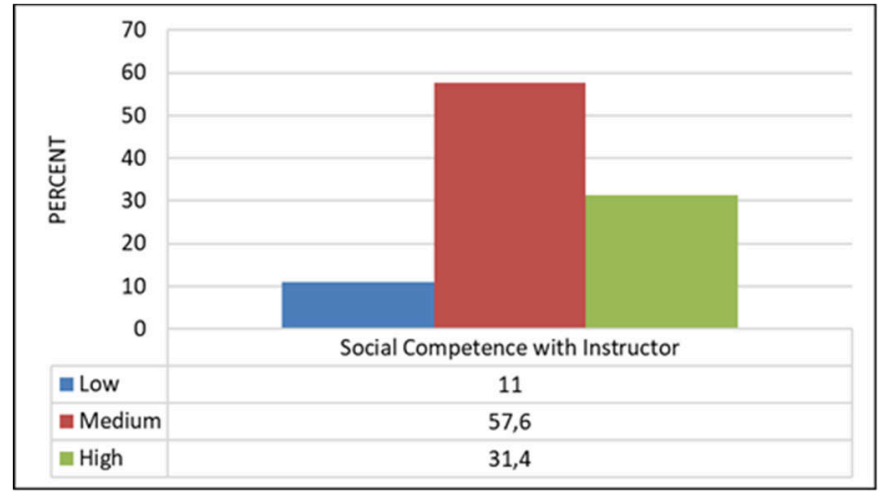

Fig 2. Level of Social Competence with Lecturers

The results showed that more than half of the students had social competence with the lecturers in the medium category with an average score of 74.58. These results indicate that the social competence of students, especially with lecturers, still needs to be improved. Students are expected to be able to establish good relationships with lecturers. A good relationship between lecturers and students is one of the factors that determine academic performance (Nyadanu et al., 2014).

The better relationship between lecturers and students can encourage students to have better achievements. The results of the research presented in Table 2 show that students have difficulty interacting with lecturers as instructors in learning activities. This difficulty arises as a result of the student's lack of self-confidence. Therefore, universities are expected to be able to encourage lecturers to develop social competence in students. Lecturers are expected to be able to develop social competence in students through learning activities (Zwaans et al., 2006). 


\subsection{Social Competence with Classmates}

Social competence with classmates is measured by six statement items, consisting of self-confidence to develop friendships, pay attention to other students' social actions, apply social interaction skills to adjust conditions, initiate interactions, and respectful manner. The distribution of students based on the responses to each statement item on social competence with classmates is presented in Table 3, and the level of social competence between students and classmates is presented in Figure 3.

Table 3. Social Competence with Classmates as Online Learning Readiness

\begin{tabular}{lcccccc}
\hline \multicolumn{1}{c}{ Item } & \multicolumn{7}{c}{ Percent } & Total \\
\cline { 2 - 6 } & 1 & 2 & 3 & 4 & 5 & \\
\hline $\begin{array}{l}\text { 1. Self-confidence develops friendships with } \\
\text { classmates }\end{array}$ & 0.8 & 8.2 & 19.6 & 28.6 & 42.9 & 100.0 \\
$\begin{array}{l}\text { 2. Self-confidence paying attention to the social } \\
\text { actions of other students }\end{array}$ & 0.8 & 5.3 & 27.8 & 32.7 & 33.5 & 100.0 \\
$\begin{array}{l}\text { 3. Confidence in applying social interaction } \\
\text { skills according to conditions }\end{array}$ & 0.4 & 2.4 & 27.3 & 35.9 & 33.9 & 100.0 \\
$\begin{array}{l}\text { 4. Self-confidence initiates interactions with } \\
\text { classmates }\end{array}$ & 1.2 & 3.3 & 20.8 & 33.9 & 40.8 & 100.0 \\
$\begin{array}{l}\text { 5. Confidence with classmates in a respectful } \\
\text { manner }\end{array}$ & 0.4 & 0.4 & 18.4 & 36.7 & 44.1 & 100.0 \\
\hline
\end{tabular}

Note: $1=$ Disagree, $2=$ Tend to disagree, $3=$ Neutral, $4=$ Tend to agree, $5=$ Agree

The results showed that more than half of the students had social competence with classmates in the high category with an average score of 81.24 . These results indicate that students' social competence with classmates is useful. The social interactions that exist between students and classmates can help students learn (Hurst et al., 2013). Higher education can take advantage of the role of friends to increase online learning readiness in students. Building good relationships with friends is also essential for students to prepare (Engin, 2017). The existence of friends has many benefits, one of which is that friends can help students to make adjustments (Buote et al., 2007). Higher education, especially lecturers, are expected to be able to encourage students to have good relationships with other students, both inside and outside the classroom. Friends also play an essential role in learning (Senior \& Howard, 2014) and academic success (Schmidt, 2020).

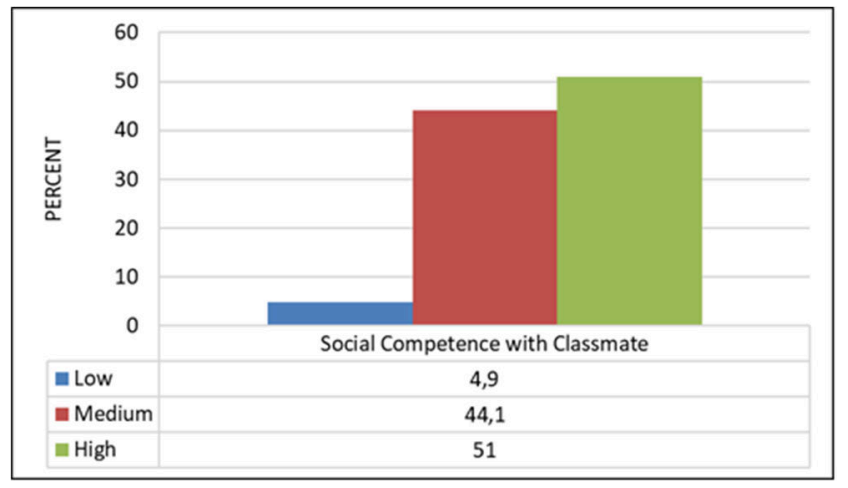

Fig 3. Level of social competence with classmates 


\subsection{Communication Competence}

Communication competence is measured by four statement items, consisting of the convenience of expressing personal opinions, the comfort of appreciating ideas, the ability to express thoughts in writing, so that others understand what is meant, and provide constructive and proactive feedback. The distribution of students based on communication competence is presented in Table 4. The level of communication competence is presented in Figure 4.

Table 4. Communication Competencies in Online Learning Readiness

\begin{tabular}{lcccccc}
\hline \multicolumn{1}{c}{ Item } & \multicolumn{7}{c}{ Percent } & Total \\
\cline { 2 - 6 } & $\mathbf{1}$ & $\mathbf{2}$ & $\mathbf{3}$ & $\mathbf{4}$ & $\mathbf{5}$ & \\
\hline $\begin{array}{l}\text { 1. Convenience of expressing personal opinions in } \\
\text { writing for others }\end{array}$ & 1.2 & 4.5 & 27.8 & 31.0 & 35.5 & 100.0 \\
$\begin{array}{l}\text { 2. Convenience in appreciating other people's } \\
\text { ideas }\end{array}$ & 0 & 1.2 & 28.2 & 39.2 & 31.4 & 100.0 \\
$\begin{array}{l}\text { 3. The ability to express thoughts in writing, so } \\
\text { that other people understand what is meant }\end{array}$ & 1.2 & 6.5 & 26.5 & 36.3 & 29.4 & 100.0 \\
$\begin{array}{l}\text { 4. Provide constructive and proactive feedback to } \\
\text { others, even if they differ }\end{array}$ & 1.6 & 4.5 & 40.4 & 32.7 & 20.8 & 100.0 \\
\hline
\end{tabular}

Note: $1=$ Disagree, $2=$ Tend to disagree, $3=$ Neutral, $4=$ Tend to agree, $5=$ Agree

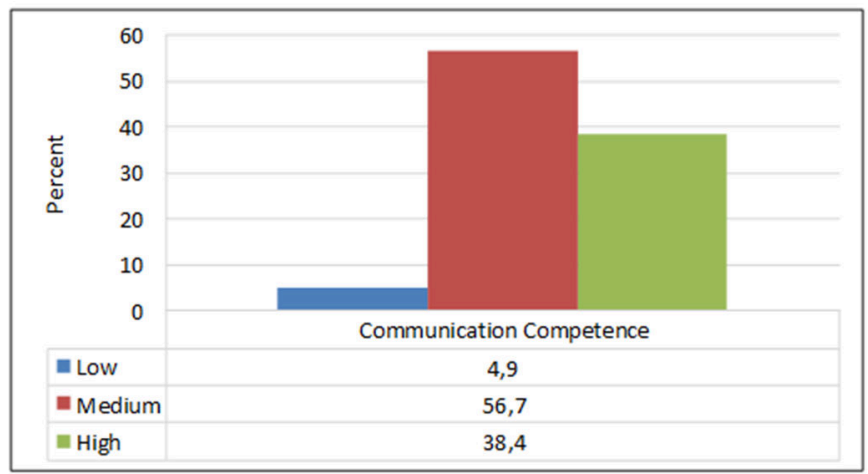

Fig 4. Levels of communication competence

The results showed that more than half of the students had communication competence in the medium category, with an average score of 77.43. These results indicate that the communication competence possessed by students still needs to be improved. The reason is that communication is an essential element for students. Students are expected to have good communication skills, including oral, written, and social behavior (Iksan et al., 2012). Students who have good communication have better learning achievement. Communication skills are one of the determinants of student success in learning activities (Aydin, 2017). In general, more than half of students have online learning readiness in the medium category with an average score of 76.08. These results support the results of previous studies which state that student readiness in online learning is in the moderate category (Rasouli et al., 2016; Adams et al., 2018). These results indicate that students' online learning readiness still needs to be improved. 


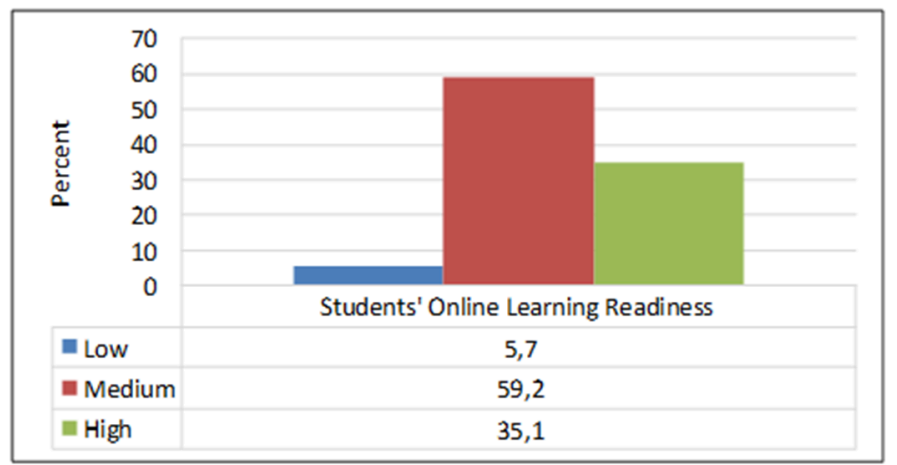

Fig 5. Levels of online learning readiness

\section{Conclusion}

The results showed that students' online learning readiness was in the medium category. More than half of the students already have technical competence, social competence with lecturers, social competence with classmates, and also useful communication competence. However, the research results also show that there are still students with low online learning readiness. Therefore, universities need to improve student competence in online learning. The readiness of students in doing online learning plays an important role in student success, especially in learning in the digital era.

\section{Acknowledgement}

The author would like to thank the Faculty of Engineering, Universitas Negeri Jakarta who has assisted in funding the implementation of this research activity through the 2020 Faculty Competitive Grants.

\section{References}

[1] Adams, D., Sumintono, B., Mohamed, A., \& Noor, N. S. M. (2018). E-learning readiness among students of diverse backgrounds in a leading malaysian higher education institution. Malaysian Journal of Learning and Instruction, 15(2), 227-256.

[2] Ali, W. G. M. (2016). Nursing Students' Readiness for e-Learning Experience. Gynecology \& Obstetrics, 6(6), 388-393. https://doi.org/10.4172/2161-0932.1000388

[3] Aydin, G. (2017). Personal Factors Predicting College Student Success. Eurasian Journal of Educational Research, 17(69), 93-112. https://doi.org/10.14689/ejer.2017.69.6

[4] Blayone, T. (2018). Reexamining Digital-Learning Readiness in Higher Education: Positioning Digital Competencies as Key Factors and a Profile Application as a Readiness Tool. International Jl. on E-Learning, 17(4), 425-451.

[5] Buote, V. M., Pancer, S. M., Pratt, M. W., Adams, G., Birnie-Lefcovitch, S., Polivy, J., \& Wintre, M. G. (2007). The importance of friends: Friendship and adjustment among 1st-year university students. Journal of Adolescent Research, 22(6), 665-689. https://doi.org/10.1177/0743558407306344

[6] Cakir, O. (2012). Students' Self Confidence and Attitude Regarding Computer: An International Analysis Based on Computer Availability and Gender Factor. Procedia - Social and Behavioral Sciences, 47, 1017-1022. https://doi.org/10.1016/j.sbspro.2012.06.772 
[7] Cigdem, H., \& Ozturk, M. (2016). Critical components of online learning readiness and their relationships with learner achievement. Turkish Online Journal of Distance Education, 17(2), 98-109.

[8] Coopasami, M., Knight, S., \& Pete, M. (2017). e-Learning readiness amongst nursing students at the Durban University of Technology. Health SA Gesondheid, 22, 300-306. https://doi.org/10.1016/j.hsag.2017.04.003

[9] Engin, M. (2017). Analysis of Students' Online Learning Readiness Based on Their Emotional Intelligence Level. Universal Journal of Educational Research, 5(12A), 32-40. https://doi.org/10.13189/ujer.2017.051306

[10] Forson, I. K., \& Vuopala, E. (2019). Online learning readiness: perspective of students enrolled in distance education in Ghana. The Online Journal of Distance Education and E-Learning, 7(4), 277-294. www.tojdel.net

[11] Garland, K., \& Noyes, J. (2005). Attitudes and confidence towards computers and books as learning tools: A cross-sectional study of student cohorts. British Journal of Educational Technology, 36(1), 85-91. https://doi.org/10.1111/j.1467-8535.2004.00440.x

[12] Hurst, B., Wallace, R., \& Nixon, S. B. (2013). The Impact of Social Interaction on Student Learning. Reading Horizons: A Journal of Literacy and Reading Horizons: A Journal of Literacy and Language Arts Language Arts, 52(4), 375-398. https://scholarworks.wmich.edu/reading_horizons

[13] Iksan, Z. H., Zakaria, E., Meerah, T. S. M., Osman, K., Lian, D. K. C., Mahmud, S. N. D., \& Krish, P. (2012). Communication Skills among University Students. Procedia - Social and Behavioral Sciences, 59, 71-76. https://doi.org/10.1016/j.sbspro.2012.09.247

[14] Martin, F., Stamper, B., \& Flowers, C. (2020). Examining Student Perception of Readiness for Online Learning: Importance and Confidence. Online Learning, 24(2), 38-58. https://doi.org/https://doi.org/10.24059/olj.v24i2.2053

[15] Nyadanu, S. D., Garglo, M. Y., Adampah, T., \& Garglo, R. L. (2014). The Impact of LecturerStudent Relationship on Self-Esteem and Academic Performance at Higher Education. Journal of Social Science Studies, 2(1), 264. https://doi.org/10.5296/jsss.v2i1.6772

[16] Rasouli, A., Rahbania, Z., \& Attaran, M. (2016). Students' Readiness for E-learning Application in Higher Education. Malaysian Online Journal of Educational Technology, 4(3). www.mojet.net

[17] Schindler, L. A., Burkholder, G. J., Morad, O. A., \& Marsh, C. (2017). Computer-based technology and student engagement: a critical review of the literature. In International Journal of Educational Technology in Higher Education (Vol. 14, Issue 1, pp. 1-28). Springer Netherlands. https://doi.org/10.1186/s41239-017-0063-0

[18] Schmidt, S. J. (2020). The importance of friendships for academic success. Journal of Food Science Education, 19(1), 2-5. https://doi.org/10.1111/1541-4329.12176

[19] Senior, C., \& Howard, C. (2014). Learning in friendship groups: developing studentsâ $€^{\mathrm{TM}}$ conceptual understanding through social interaction. Frontiers in Psychology, 5. https://doi.org/10.3389/fpsyg.2014.01031

[20] Wei, H.-C., \& Chou, C. (2020). Online learning performance and satisfaction: do perceptions and readiness matter? Distance Education, 41(1), 48-69. https://doi.org/10.1080/01587919.2020.1724768

[21] Yimer, M., Abera, B., Mulu, W., \& Bezabih, B. (2014). Knowledge, Attitude and Practices of High Risk Populations on Louse- Borne Relapsing Fever in Bahir Dar City, North-West Ethiopia. Science Journal of Public Health, 2(1), 15-22. https://doi.org/10.11648/j.sjph.20140201.13

[22] Yu, T., \& Richardson, J. C. (2015). An exploratory factor analysis and reliability analysis of the student online learning readiness (SOLR) instrument. Online Learning Journal, 19(5). https://doi.org/10.24059/olj.v19i5.593

[23] Zwaans, A., Ten Dam, G., \& Volman, M. (2006). Teachers' goals regarding social competence. In European Journal of Teacher Education (Vol. 29, Issue 2, pp. 181-202). 
https://doi.org/10.1080/02619760600617375 